THURSDAY, AUGUST 9, 1877

\section{ELECTRICITY IN WAR}

THE important rôle played by electricity in modern warfare affords an excellent example of the influence which science has of late exerted in naval and military affairs. It is no isolated example of scientific warfare that we have here to deal with, for the electric fluid has in a great measure changed our whole practice of war, and bids fair to revolutionise it still more in the future. Every soldier or sailor, if he desires to make his mark, must be something of an electrician, for there seems to be no limit to the useful applications of the galvanic spark in battle. Broadly, we may divide these applications under three heads; namely, the employment of electricity for signalling, for the explosion of charges, and lastly, for illumination, both for the purposes of attack or defence, it being a difficult matter to decide in which connection the electric spark fulfils the most important duty.

To begin with the telegraph. All will agree that it is wellnigh impossible to overrate the advantages which this rapid means of communication gives to the general, in these days, when the line of battle sometimes extends for a dozen miles. Let the commander occupy the most central position, a long time must elapse before his aidesde-camp can communicate with one wing or the other. Assisted by the electric telegraph, however, the general is as close to his subordinates as if he were within shouting distance. Even a brigade of horse artillery, or a cavalry division advancing at a gallop, can carry its telegraph equipment with it, the operators accompanying a flying column of this nature with but very little difficulty. The wire drums are started off at a gallop, the cable being unwound as the carts proceed, and a sergeant on horseback with a "sounder" to his ear, in connection with one end of the wire, receives the general's commands as soon almost as they are spoken. The movement countermande? or a retreat ordered, the cable is again wound up as readily as it was laid down, and the telegraphers make good their return with the rest of the troops. Where ordinary movements are executed, use is of course made of the telegraph wagon, a comfortable little office on wheels, furnished with all things necessary for the receipt and despatch of messages, but this convenience is naturally out of place where a rapid change of front, or some speedy flank movement has to be executed.

Coming next to the explosion of charges by means of the electric spark, we enter upon a phase of war-science which bids fair to grow to infinite proportions. Both Franklin and Priestley suggested the employment of electricity in this connection more than a hundred years ago, but it is very recently indeed that we have been in a position to make proper use of this valuable agent as a means of firing charges at a distance. In fact, at the present moment we have by no means exhausted research in this direction, and we find scientific soldiers and sailors still at variance with one another as to the best plan of using the electric current for firing purposes. One of the first applications made of the subtle fluid was in the removal of the wreck of the Royal George, at Spithead, nearly fifty years ago, when the explosion of the VoL, xvi.-No. 406 charges was brought about by what is termed a wire-fuse, or in other words a short piece of platinum thread stretched between two copper wires. The platinum bridge having less conducting power than the copper wires, presents a considerable amount of resistance to any current of electricity that passes, and, in doing this, becomes so heated, as to be capable of igniting any particles of gunpowder in contact with it. A wire-fuse of this description has simply to be placed in the middle of a charge, and if then a current of electricity is passed from a battery along the wire in connection with the fuse, instantaneous ignition is the result. This simple method of firing charges under water was a vast improvement over the old one in use by our engineers, which consisted in leading up a metal pipe from the charge to the surface of the water; the outlet of the pipe was placed as far as possible from the charge beneath the water, and then a ladle full of red hot shot was emptied down it, and so reached the gunpowder below, which thereupon exploded if the iron fragments had not become too cool in transit.

But for many purposes the wire-fuse is ill-adapted to the military and naval services. A voltaic battery is necessary to evolve the low-tension electricity required to yield sufficient resistance and heat, and such a battery made up of metal plates, and involving the use of acids, is an awkward apparatus to carry in the field. Already in 1853 , this fact seems to have occurred to a Spanish officer, Col. Verdu, who determined to see what could be done in the way of exploding gunpowder by a spark, or in other words, by high tension electricity. Aided by a Ruhmkorff coil he succeeded in firing half-a-dozen charges simultaneously, and although the discharge was sometimes a matter of considerable uncertainty, to Verdu certainly belongs the credit of having been the first soldier to apply electricity in this way to the firing of one or more mines. Whoatstone and Abel followed in Verdu's footsteps, and while the former directed his attention to the construction of a frictional apparatus of a portable nature, which should be suitable for military use, the latter busied himself in the preparation of a fuse inclosing a compound more delicately explosive than gunpowder, a fuse, by the way, which still retains an important place among our warlike stores.

It was in the China war of 1860 that we first find an electric firing apparatus forming part of an army equipment. In this case the outfit was of a somewhat clumsy nature. A conveyance, in shape and size much resembling a baker's barrow, contained a monster horse-shoe magnet, and it was the sudden disruption of its armature from this magnet which generated the spark to fire the fuse. A few years afterwards, this ponderous conveyance gave place to a neat little mahogany box about a foot cube, which contained half a dozen small but powerful magnets, in the field of which the armatures were made to revolve with exceeding celerity; and it is by means of such an apparatus that to day we are enabled to fire a score of charges at a time, the wires branching off from the instrument to a distance of a hundred yards or more. But, nevertheless, we have yet to devise, it seems, an efficient exploding apparatus capable of igniting both low and high tension electric fuses.

As everybody knows, it is by reason of electricity being employed to fire explosive charges that torpedo warfare has 
of late attained to so important a position. In the Whitehead, or fish-torpedo, the electric fluid, it is true, plays no part, but this is the only notable exception. In the floating torpedo, the moored torpedo, and the spar-torpedo, electricity is the life and soul ; at one moment the machine is but a floating buoy or sunken impediment, the next it is transformed into a terrible volcano. A feeble current of electricity flashing along the wire, has on the instant sufficed to bring about the fatal change.

Passing from torpedo warfare and the recent attempts that have been made to turn electricity to account in the construction of self-steering launches, we come to a scarcely less important matter, that of firing guns by the electric spark. Not only are guns at proof and those under experiment so ignited, but on board the modern ironclad it is the custom now-a-days to fire broadsiaes in this wise also. By leading wires from every gun to one point, which is specially adapted for observation, the double advantage is secured of bringing about the firing at the most opportune moment, and of securing a simultaneous discharge. Some experiments made in Germany have proved beyond doubt that an armour plate struck instantaneously in this way by several shot, may be effectively broken up, whereas the ordinary broadside fire, brought about by gunners at word of command is incapable of doing so. The wires may be led into an observing tower, or half way up the mainmast if need be, and here the firing officer can calmly consort his measures undisturbed by the smoke, and noise, and bustle going on below him. $\mathrm{He}$ is provided with proper sights, and the guns being laid in accordance with his orders, he can watch the opportunity for firing as well as if he had his eye to the weapons themselves.

Finally, we have the use of the electric light in warfare. It is the most recent application of all of this wonderful agent, and we should hesitate to say how extensive may hereafter be the employment of electricity in this connection. In the Franco-German war, the first use of this powerful source of illumination was made by the French engineers, and from the forts around Paris the electric rays were made to sweep in all directions, to watch for hostile troops engaged in the operation of mining. Bodies of soldiers upwards of a mile distant could be plainly seen by the vivid light of the electric lamp, and working parties were frequently compelled to abandon their object in the presence of this powerful detector. As a means of discovering the approach of torpedo launches at night, the electric light will obviously be of value, and already a trial of it has been made in several of Her Majesty's ships. The Alexandra, the flagship of the Mediterranean fleet, is provided with an electric lamp, worked by one of Wilde's powerful machines, so that the efficiency of the apparatus may be practically tested. Experiments, however, have already shown what the electric rays are capable of doing, and a low torpedo-launch cannot approach within a thousand yards without detection, while if painted of a neutral grey, so as the better to escape observation by day, the vessel, it appears, is all the more perceptible under electric illumination. Steamers, we are told, are peculiarly liable to be detected by an electric lamp, since the rays are reflected by the steam and smoke as effectively as if the latter were a solid screen. How valuable, too, the electric light on board ship must prove for signalling purposes may be gathered from the fact that the Dungeness light, which was the first one of an electric nature constructed in this country, can be seen on a clear night at a distance of thirty miles with all the brilliancy of a star of the first magnitude.

\section{H. BADEN PRITCHARD}

\section{THE GEOLOGY OF THE VIENNA WATER SUPPLY}

Geologie der Kaiser Franz-Fosefs Hochquellen-Wasserleitung. Eine Studie in den Tertiär-Bildungen am Westrande des Alpmen Theiles der Niederung von Wien. By Felix Karrer. (K.K. geolog. Reichsanstalt. Vienna, I877.)

7 HE publications of the Austrian Geological Institute 1 are deservedly noted for their number, their fulness, and the beauty of their illustrations. Especially are the large quarto memoirs published under the name of Abhandlungen remarkable in the latter respects. Consisting usually of complete monographs, sometimes purely palæontological, but more often blending stratigraphy with palæontology in a manner which is too seldom resorted to in this country, these handsome volumes are quite independent of, whils they frequently illustrate, the maps issued by the same authority.

The present work forms vol. ix. of this important series. In many ways it is unlike its forerunners, but it resembles them in its completeness and in the finished character of its plates. Although eminently local in interest yet so many points are touched upon--or rather fully discussed -in Dr. Karrer's memoir that it appeals to the civil engineer, the hydrologist, the archæologist, and the chemist in almost as great a degree as to the geologist and the systematic palæontologist.

This great closely-printed book of more than four hundred pages, with its numerous tables and large folding plates, is strictly what its title implies, viz., an account of the geology exposed by the engineering works recently carried out in order to bring the waters of the Kaiserbrunnen and Stixtenstein springs to Vienna, a distance of some twelve Austrian or fifty-five English miles.

All the leading features of this section could probably have been described and commented on with apparent fulness in a short paper in the Verhandungen of the Institute, but the aim of the author has been to raise the character of his memoir from that of a passing pamphlet to that of a thoroughly exhaustive record of all the facts - the seemingly unimportant as well as the obviously valuable-which could be brought within the natural limits of his subject. In this object he has perfectly succeeded, and the result is an orderly collection of minute stratigraphical and other details such as, we believe, have never before been brought together with reference to so small an area.

From Kaiserbrunnen at the foot of the Schneeberg and from Stixtenstein a little further north to the very streets of the Capital, or, geologically speaking, from the triassic heights of the Noric Alps to the drift and alluvium overlying the Tertiary beds of this Alpine portion of the Vienna Basin, only those valleys across which the aqueduct replaced the cutting and the tunnel were left unsearched and unplotted by Dr. Karrer. Every bed, band, thinning, 